\title{
Original
}

\section{Periodontal Treatment Needs of Members of the Ground Self-Defense Force}

\author{
陸上自衛隊隊員の娄周治療の必要性
}

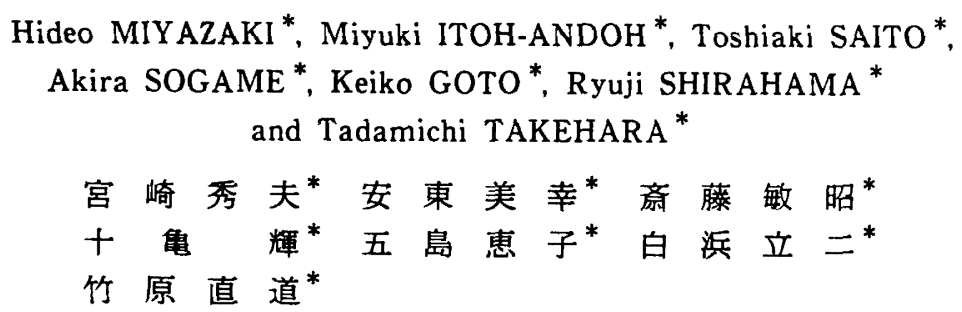

Received June 11, 1987 ; accepted September 12, 1987

\begin{abstract}
概要：北九州市に舸屯する陸上自衛隊の隊貝942名を対象に，CPITNによる掬周疾患有病とその処直の必

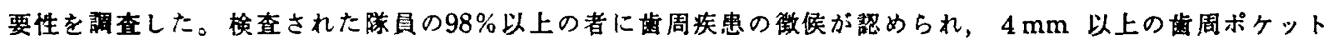
所有者率は，10代の40\%から45-64歳群の83\%まで増龄的に高くなった。また，30-44歳群では18\%，45-64嵅 群では $41 \%$ の者が複雑な処置を必要とし，全年龄群の $95 \%$ 以上がスケーリングを必要としていた。以上の結 果は，我々の一連の調查や他の研究者が報告した集団と比較して，この自衛隊は歯周疾患のハイリスク集団 であることを示している。したがって，この陸上自衛隊では，歯周疾患に対する予防管理体制（定期検查とス ケーリング処圈）の確立が早急に望まれる。
\end{abstract}

\section{Koy words: CPITN, Periodontal disease, Ground Self-Defense Force}

索引用語 : CPITN, 苗周疾患, 陸上自衛隊

\section{Introduction}

The treatment of periodontal diseases is more complicated and requires a longer time period than that of dental caries. Periodontal tissue (alveolar bone) which is destroyed by these diseases cannot recover its original function, once it is damaged. Moreover, the effects of the treatment are dependent on each patient's care. Thus, the efforts and skill of the dentist do not necessarily result in a successful periodontal recovery, in comparison to dental caries. It is more difficult for individuals to know whether or not they have a periodontal disease, or to what degree an existing disease has progressed. Because of this, dentists have been advocating the necessity of periodontal disease prevention and prompt treatment of the diseases, once signs of the diseases are found. This study surveyed aspects of periodontal diseases, using the Community Periodontal Index of Treatment Needs (CPITN) ${ }^{1)}$, in various age groups and

* Department of Preventive Dentistry, Kyushu DentalCollege (Director : Prof. Tadamichi TAKEHARA)

* 九州莯科大学口胵衙生学教室（主任：竹原直道教授) 
communities, and clarified the actual state of the diseases ${ }^{2-8}$. In this paper, the prevalence and treatment needs of periodontal diseases, in members of the Ground Self-Defense Force, were surveyed.

\section{Materials and Methods}

In April 1987, a survey was made of the prevalence and treatment needs of periodontal diseases, in 942 members aged 18 to 58 years, from the Ground Self-Defense Force, camped in Kitakyushu. Five examiners assessed the subject's periodontal status, using the WHO periodontal examination probe (Yamaura Seisakusho Ltd.), according to the CPITN by Ainamo et al.1) Care was taken to follow the original method ${ }^{11}$ as closely as possible, but, the mid-buccal/labial and mid-lingual/palatal regions were also examined as probing points, in addition to the four line angles around the gingival margin of the index teeth ${ }^{9)}$. The data were totaled using an NEC PC-9801/F2 Personal Computer.

\section{Results}

Table 1 shows the percentage of persons showing signs of periodontal diseases (the rate of those giving the most severe symptomatic grade). Over $98 \%$ of the members showed some signs of periodontal diseases. Pathologic pockets $6 \mathrm{~mm}$ or deeper (deep pockets; Code 4) were observed in 2 to $3 \%$ of the members under the age of 30 . The percentage of members having these pathologic pockets increased with age, and reached $41 \%$ among those aged $45-58$ years. Pathologic pockets $4 \mathrm{~mm}$ or deeper (Codes 3 and 4) were observed in $40 \%$ of the 18-to 19 -year-old members; the percentage of members having these pathologic pockets also increased with age, and reached $83 \%$ in the 45 - to 58 -year-old age group.

Table 2 shows the mean number of sextants affected. The mean number of sextants exhibiting gingival bleeding after gentle probing, supra- or subgingival calculus, or more serious symptoms, did not differ with age, for the members between 20 and 58 years old, 4.9-5.1 and 4.4-4.7 sextants, respectively. The mean number of sextants exhibiting pathologic pockets increased with age. Teeth for assessment were missing in less than 1 sextant for the 30- to 58-year-olds.

Eighteen to $41 \%$ of the members over 30 years of age were found to require complex treatments. The majority were diagnosed as requiring oral hygiene instruction and oral prophylaxis (Table 3 ).

Table 1 Percentage of persons affected $(\mathrm{N}=942)$

\begin{tabular}{ccccccc}
\hline Age & $\mathrm{N}$ & $\begin{array}{l}\text { No } \\
\text { periodontal } \\
\text { disease }\end{array}$ & $\begin{array}{l}\text { Bleeding } \\
\text { only }\end{array}$ & Calculus & \multicolumn{2}{c}{ Pocket depth } \\
\hline $15-19$ & 66 & 2 & 3 & 56 & 38 & 2 \\
$20-29$ & 364 & 2 & 2 & 54 & 40 & 3 \\
$30-44$ & 268 & 1 & 3 & 24 & 54 & 18 \\
$45-64$ & 244 & 2 & 1 & 13 & 42 & 41 \\
\hline
\end{tabular}

Table 2 Mean number of sextants affected

\begin{tabular}{ccccccc}
\hline Age & N & Bleeding & Calculus & \multicolumn{2}{c}{ Pocket depth } & \multirow{2}{*}{$\begin{array}{c}\text { Missing } \\
\text { sextants }\end{array}$} \\
\hline $15-19$ & 66 & 4.7 & 3.7 & 0.8 & 0.0 & 0.0 \\
$20-29$ & 364 & 5.1 & 4.4 & 0.9 & 0.0 & 0.0 \\
$30-44$ & 268 & 5.1 & 4.6 & 2.3 & 0.4 & 0.1 \\
$45-64$ & 244 & 4.9 & 4.7 & 3.2 & 1.0 & 0.3 \\
\hline
\end{tabular}


Table 3 Service requirements (\%)

\begin{tabular}{ccccc}
\hline Age & $\mathrm{N}$ & $\begin{array}{l}\text { Hygiene } \\
\text { instruction }\end{array}$ & Prophylaxis & $\begin{array}{c}\text { Complex } \\
\text { treatment }\end{array}$ \\
\hline $15-19$ & 66 & 98 & $95(3.7)$ & $2(0.0)$ \\
$20-29$ & 364 & 98 & $97(4.4)$ & $3(0.0)$ \\
$30-44$ & 268 & 99 & $96(4.6)$ & $18(0.4)$ \\
$45-64$ & 244 & 98 & $96(4.7)$ & $41(1.0)$ \\
\hline
\end{tabular}

( ) : Mean number of sextants affected

\section{Discussion}

For adults, in whom the susceptibility to dental caries is lower, the main concern in terms of dental health is prevention and treatment of periodontal diseases. In recent years, surveys on periodontal diseases using CPITN have been conducted in order to obtain the basic data necessary for the management of industrial dental health. The Self-Defense Force is somewhat different from other business organizations, but its members could be handled as subjects of industrial dental health care. It is interesting to determine the periodontal treatment needs of members of the Self-Defense Force, and it is neccessary to plan a dental health program.

According to a survey of periodontal diseases among the members of the Maritime Self-Defense Force ${ }^{(0)}$, more than $96 \%$ of the members had some signs of periodontal disease. With an increase in age, the percentage of members having only gingival bleeding after gentle probing decreased from $25 \%$ to $9 \%$, while the percentage of those having supra- or subgingival calculus decreased from $40 \%$ to $20 \%$. Conversely, with an increase in age, the percentage of members having pathologic pockets 4 or $5 \mathrm{~mm}$ deep (shallow pockets) increased from $30 \%$ to $52 \%$, while those having pathologic pockets $6 \mathrm{~mm}$ or deeper (deep pockets) increased from $2 \%$ to $17 \%$. The prevalence and treatment needs of periodontal diseases, in members of the Maritime Self-Defense Force, are similar to those of the populations reported by other investigators ${ }^{2,4,11-13)}$.

The percentage of members showing some signs of periodontal diseases in this survey of the Ground Self-Defense Force was as high as $98 \%$. The percentage of members having pathologic pockets, a serious symptom of the disease, was very high, ranging from $40 \%$ in the teenage group to $83 \%$ in the 45- to 64-year-old group. The percentage of members having pathologic pockets $6 \mathrm{~mm}$ or deeper was $18 \%$ and $41 \%$, in the 30 - to 44 -year-old group and the 45 - to 64 -year-old group, respectively. When comparing the members of the Ground Self-Defense Force with the members of the Maritime SelfDefense Force ${ }^{10}$, no difference was revealed in the percentage of members affected; however, in the Ground Self-Defence Group, the percentage of members having deep pockets was 3 times higher in the 30- to 44-year-old group, and 2 times higher in the 45- to 64-year-old group. In addition, the Ground Force members strikingly outnumbered the Maritime Force members, in terms of the mean number of sextants affected. The data obtained from these members of the Ground Self-Defense Force were similar to the data obtained from a high risk group (inpatients of a mental hospital ${ }^{8}$ ) of periodontal diseases, although fewer subjects had missing teeth in the former group.

In the Ground Self-Defense Force, jobs are difficult and irregular, in terms of work time. Aside from the job status in the Maritime Force, which is unknown to us, the members of the Ground Force, who were the subjects of the present survey, had maneuvers for approximately half of a month. During maneuvers, they dug trenches and slept there. They were not able to rinse their 
mouth on many occasions, due to a lack of water. It is impossible for them to carry out plaque control, by tooth brushing, during these maneuvers. Thus, it is very probable that such a life style is a major cause for the high prevalence of periodontal diseases, and their aggravation. In addition, the members often grit their teeth under stress, which causes overloading on the periodontal tissue. This may be a precipitating factor of their periodontal diseases.

There were few persons having missing teeth to be assessed, among the Ground Force members. Even in the 45- to 64-ycar-old group, the mean number of missing sextants was 0.3 . This result seems to indicate that, unlike the inpatients of a mental hospital ${ }^{8)}$, who also are a high risk group for periodontal diseases, members of the Ground Force are probably concerned about dental health, and have the self-descipline to perform plaque control. This estimation is also supported by the large number of patients who visit the dental clinic in the Defense Camp. The present survey revealed that almost all of the Ground Force members require prophylaxis, and that several require complex treatment of periodontal diseases. In view of the uniqueness of the jobs in the Ground Self-Defense Force, thorough performance of prophylactic treatment is a more realistic goal than that of self-care. Since the number of persons requiring complex treatment increases rapidly after 30 years of age, recall and prophylactic treatment should be focused on this age group in the Ground Self-Defense Force. Dental health education and oral hygiene instruction regarding periodontal diseases are essential, but it is also desirable for the Ground Self-Defense Force to establish a prophylactic management system for periodontal diseases as early as possible.

\section{References}

1) Ainamo, J., Barmes, D., Beagrie, G., Cutress, T., Martin, J. and Sardo-Infirri, J. : Development of the World Health Organization (WHO) Community Periodontal Index of Treatment Needs (CPITN), Int. Dent. J., $32 ; 281,1982$.

2) Takehara. T., Miyazaki, H., Andoh, A., Hanada, N., Itoh, M., Nakayama, K., Saitoh, T., Sogame, A. and Saeki, E.: A survey of periodontal disease in new patients at Kyushu Dental College Hospital, J. Kyushu Dent. Soc., 40;427, 1986, (in Japanese).

3) Miyazaki, H., Hanada, N., Nakayama, K., Sogame, A., Shigeoka, T., Kojima, M., Matsuda, S. and Takehara, T.: Periodontal treatment needs for the students of $\mathrm{Na}$ gashima High School, Kagoshima prefecture, J. Kyushu Dent. Soc., 40 ; 1137, 1986.

4) Miyazaki, H., Hanada, N., Itoh-Andoh, M., Sogame, A., Sakuma, M. and Takehara, T.: Periodontal treatment needs of industrial workers, J. Dent. Hlth, $37 ; 150$, 1987.

5) Miyazaki, H., Yamashita, Y., Saito, T., Sogame, A., Shigeoka, T., Sakuma, T. and Takehara, T.: Assessment of periodontal status using CPITN for elementary school chidren, J. Dent. Hlth, 37 ; 167, 1987.

6) Miyazaki, H., Itoh-Andoh, M., Yamashita, Y., Saito, T., Sogame, A., Goto, K. and Takehara, T.: CPITN assessment of periodontal status in junior high school children, J. Dent. Hlth, 37 ; 220, 1987.

7) Miyazaki, H., Soh, Y., Kuo, M. Y., Wang, T. M., Saito, T., Nakayama, K., Sogame, A., Iha, T. and Takehara, T.: Periodontal treatment needs in college students in Taichung, Taiwan and Kitakyushu, Japan, J. Kyushu Dent. Soc., 41 ; 812, 1987.

8) Miyazaki, H., Itoh-Andoh, M., Yamashita, Y., Saito, T., Goto, K. and Takehara, T. : Prevalence and treatment needs of periodontal disease in the inpatients at a mental hospital, J. Kyushu Dent. Soc., 41 ; 801, 1987.

9) Suzuki, K.: The matters we have to put in order at survey using CPITN (Community Periodontal Index of Treatment Needs), The Nippon Dental Review, 513 ; 161, 1985, (in Japanese).

10) Sasaki, Y., Takahashi, Y., Arita, K. and Ishii, T.: Approaches to the management of periodontal diseases in the Maritime SelfDefense Force. III. Estimating periodontal treatment needs and dental man-power requirements based on CPITN, J. Dent. Hlth, $36 ; 364$, 1986, (in Japanese). 
11) Kitahara, M., Takano, K., Horiuchi, K., Matsusaka, K. and Mukai, S. : A survey on periodontal disease in Fujisawa with CPITN (WHO), J. Dent. Hlth, $34 ; 576,1984$, (in Japanese).

12) Ishikawa, I., Honma, S., Hagiwara, S., Asai, H., Osada, Y., Izumi, Y., Watanabe, H., Izumizawa, K. and Noguchi, T.: Epidemiological survey on periodontal disease in the employees of two banks with CPITN (Community Periodontal Index of Treatment Needs) - The primary report-, J. Japan. Ass. Periodont., 26 ; 767, 1984, (in Japanese).

13) Suzuki, Y., Kouyama, Y., Maita, E. and Horiuchi, H. : A survey of periodontal diseases using Community Periodontal Index of Treatment Needs (CPITN) suggested by the WHO, J. Japan. Ass. Periodont. 27 ;
473, 1985, (in Japanese).

14) Hagiwara, S., Honma, S., Asai, H., Konno, T., Ohshima, M., Izumizawa, K., Noguchi, T. and Ishikawa, I. : Epidemiological survey on periodontal disease in the employees of two banks with CPITN (Community Periodontal Index of Treatment Needs) -The second report-, J. Japan. Ass. Periodont., 27 ; 635, 1985, (in Japanese).

15) Kani, M., IIno, S., Kani, T., Isozaki, A., Tsutaho, T., Hirose, A., Okuno, M., Kato, H., Ikawa, E., Kuwahara, S., Kajita, H. and Okuda, M.: The CPITN survey on industrial workers -Relationship between CPITN and VPI, periodontal subjective sym. ptoms-, J. Dent. Hlth, 36; 296, 1986, (in Japanese). 